\title{
Helicobacter pylori management: How to improve the therapeutic confusion in practice
}

\author{
Nicholas J Talley MD PhD FRACP
}

NJ Talley. Helicobacter pylori management: How to improve the therapeutic confusion in practice. Can J Gastroenterol 2003;17(Suppl B):21B-24B.

There appears to be a disconnect between current guidelines for Helicobacter pylori testing and treatment, and clinical practice, including physician beliefs and actual prescribing patterns. In particular, there are markedly different approaches in primary and secondary care, and country-specific differences in eradication therapy for $\mathrm{H}$ pylori infection. Although most physicians do not believe that $H$ pylori causes nonulcer dyspepsia, the majority appear to prescribe eradication. Less information is available on the management of $\mathrm{H}$ pylori infection and gastroesophageal reflux disease, and more marked differences in attitudes and practice occur in this condition. Even in peptic ulcer disease, where most clinicians both in primary and in secondary care believe $H$ pylori should be eradicated, there is often a breakdown in the translation of this belief into practice. There is also confusion in terms of treatment regimens applied for $\mathrm{H}$ pylori eradication. Eradication regimens are less successful in practice than in clinical trials. Furthermore, a sizable proportion of patients with peptic ulcer remain symptomatic despite cure of the ulcer diathesis, which may undermine confidence. Therapeutic confusion about what to prescribe, side effects limiting compliance, bacterial resistance, and socioeconomic factors may all impair therapeutic success with eradication therapy in practice. Unfortunately, it has been well documented that guidelines alone are likely to have little or no impact in practice. Publication in a journal is unlikely to lead to effective implementation in primary care. On the basis of available evidence, clinical behaviour is most likely changed when guidelines are developed by the peer group of clinicians for whom they were intended, are disseminated through a specific educational program, and are implemented by applying, preferably during the consultation, specific reminders.

\section{L'Helicobacter pylori : Les mécanismes fonda- mentaux d'une guérison clinique}

\begin{abstract}
Il semble exister une dichotomie entre les directives actuelles relativement aux tests et au traitement de l'Helicobacter pylori et la pratique clinique, y compris les opinions des médecins et les modèles posologiques. Plus particulièrement, on remarque des démarches fort différentes dans les soins de première et de deuxième ligne, ainsi que des différences selon le pays dans la thérapie d'éradication de l'infection au $H$ pylori. Bien que la plupart des médecins ne croient pas que le $H$ pylori soit responsable de la dyspepsie non nucléaire, la majorité semblent prescrire l'éradication. On possède moins d'information sur la prise en charge de l'infection au $\mathrm{H}$ pylori et du reflux gastro-œsophagien pathologique, et des différences plus marquées d'attitudes et de pratique s'observent alors. Même en cas d'ulcère peptique, alors que les cliniciens de première et de deuxième ligne pensent que le $H$ pylori devrait être éradiqué, on remarque souvent une rupture au moment de transposer cette opinion dans la pratique. Il existe également une confusion pour ce qui est des posologies de traitement appliquées à l'éradication du $H$ pylori. Les posologies d'éradication sont moins efficaces en pratique que dans le cadre des essais cliniques. De plus, une proportion appréciable de patients atteints d'ulcère peptique demeure symptomatique malgré le traitement curatif de la diathèse ulcéreuse, ce qui peut miner la confiance du médecin. La confusion thérapeutique quant à ce qu'il faut prescrire, aux effets secondaires limitant le respect de l'ordonnance, à la bactériorésistance et aux facteurs socioéconomiques pourrait nuire au succès de la thérapie d'éradication dans la pratique. Malheureusement, il est bien documenté que les seules directives cliniques sont peu susceptibles d'avoir des répercussions dans la pratique. La publication dans un journal donne rarement lieu à l'implantation efficace d'un traitement de première ligne. D'après les analyses systématiques, le comportement clinique peut être modifié lorsque des directives sont élaborées à l'intention des cliniciens, sont diffusées par l'entremise d'un programme d'éducation spécifique et sont implantées par l'application, de préférence pendant la consultation, de rappels destinés aux patients.
\end{abstract}

Key Words: Clinical practice; Guidelines; H pylori; Nonulcer dyspepsia; Peptic ulcer; Therapy

工elicobacter pylori infection is an important cause of dyspepsia 1 in practice, and 'test and treat' has been established as the standard of care in the absence of red flags to cost effectively eliminate the ulcer diathesis (1). Efficacious combination therapies for eradication of $H$ pylori infection have been tested in clinical trials, leading to treatment recommendations by international and national consensus conferences (2-4). However, a disconnect between guidelines and clinical practice is evident based on surveys of practice over the past decade $(5-20)$. Here, the issue of therapeutic confusion in clinical practice is reviewed and practical recommendations are presented to try to overcome this problem.

\section{EVIDENCE FOR THERAPEUTIC CONFUSION BY DISEASE INDICATION}

The best evidence suggests that eradication of $H$ pylori in nonulcer dyspepsia (NUD) results in a small benefit; the number needed to treat is around one in 15 , although it may be even less in clinical practice $(21,22)$. Understandably, the place of treatment of $H$ pylori in NUD remains confusing because clinical trials have most frequently reported negative results, albeit with a small, usually nonsignificant trend in favour of eradication in many (21). Indeed, meta-analyses have also reported conflicting conclusions, and the experts disagree $(21,23-27)$. No wonder opinion and

This article was originally presented at a conference entitled "Helicobacter pylori: Basic Mechanisms to Clinical Cure 2002", sponsored by Axcan

Pharma, November 10-14, 2002, Maui, Hawaii

Department of Medicine, University of Sydney, Nepean Hospital, New South Wales, Australia

Correspondence and reprints: Dr NJ Talley, Department of Medicine, University of Sydney, Nepean Hospital, PO Box 63 Penrith, New South Wales 2751, Australia. Telephone +61-2-4734-2613, fax +61-2-4734-2614, e-mail ntalley@med.usyd.edu.au 
TABLE 1

Surveys of physicians' attitudes to Helicobacter pylori infection

\begin{tabular}{|c|c|c|c|c|c|c|c|c|c|c|c|c|c|c|}
\hline \multirow{3}{*}{$\begin{array}{l}\text { Author } \\
\text { (reference) }\end{array}$} & \multirow{3}{*}{$\begin{array}{l}\text { Physicians } \\
\text { surveyed, } \mathrm{n}\end{array}$} & \multirow{3}{*}{$\begin{array}{l}\text { Physician } \\
\text { speciality }\end{array}$} & \multirow{3}{*}{$\begin{array}{c}\text { Response } \\
\text { rate (\%) }\end{array}$} & \multirow{3}{*}{$\begin{array}{l}\text { Location and } \\
\text { year of survey }\end{array}$} & \multicolumn{10}{|c|}{ Proportion (\%) of respondents supporting treatment of $\boldsymbol{H}$ pylori } \\
\hline & & & & & \multicolumn{2}{|c|}{$\begin{array}{l}\text { Duodenal } \\
\text { ulcer }\end{array}$} & \multicolumn{2}{|c|}{$\begin{array}{c}\text { Gastric } \\
\text { ulcer }\end{array}$} & \multicolumn{2}{|c|}{$\begin{array}{c}\text { Nonulcer } \\
\text { dyspepsia }\end{array}$} & \multicolumn{2}{|c|}{ GERD } & \multicolumn{2}{|c|}{$\begin{array}{l}\text { PPI triple } \\
\text { therapy as } \\
\text { first choice }\end{array}$} \\
\hline & & & & & PCP & GE & PCP & GE & PCP & GE & PCP & GE & PCP & GE \\
\hline Christensen et al (7) & 636 & PCP, GE & 63 & Europe 1992 & 73 & 87 & & & & & & & & \\
\hline Milne et al (8) & 1037 & GE & 65 & UK 1993 & & 80 & & 38 & & 69 & & & & \\
\hline Hirth et al (9) & 1119 & PCP, GE, HI & 30 & USA 1994 & 65 & 99 & & & & & & & & \\
\hline Fendrick et al (10) & 4500 & PCP, GE & 30 & USA 1994 & 64 & 99 & & & & & & & & \\
\hline Boekema et al (11) & 422 & GE & 54 & Netherlands 1995 & & 98 & & 91 & & 32 & & 30 & & 40 \\
\hline Breuer et al (12) & 2394 & PCP, GE & 32 & Germany 1995 & 74 & 86 & 84 & 85 & 41 & 27 & & & & \\
\hline Breuer et al (13) & 5994 & PCP, GE, HI & 52 & USA 1996 & 95 & 100 & 97 & 99 & 66 & 43 & & 50 & 16 & 40 \\
\hline \multicolumn{15}{|l|}{ Martinez-Sanchez } \\
\hline et al (14) & 359 & PCP & 79 & Spain 1997 & 96 & & 96 & & 15 & & & & 99 & \\
\hline Binek et al (15) & 363 & GE & 48 & Switzerland 1997 & & 100 & & 100 & & 79 & & & & 53 \\
\hline Martin et al (16) & 1832 & PCP, GE & 67 & Scandinavia 1997 & 99 & 99 & 90 & 90 & 57 & 41 & & & & \\
\hline Sharma et al (17) & 1000 & GE & 31 & USA 1998 & & 100 & & 100 & & & & 54 & & 69 \\
\hline \multicolumn{15}{|l|}{ Olafsson (18) } \\
\hline and Berstad (18) & 1718 & GE & 36 & Scandinavia 1998 & & 99 & & 99 & & 16 & & 11 & & 94 \\
\hline Zoorob et al (19) & 1500 & PCP & 49 & USA 1998 & 48 & & & & & & & & 27 & \\
\hline Maconi et al (20) & 100 & PCP & 100 & Italy 1998 & 64 & & & & 66 & & & & 88 & \\
\hline
\end{tabular}

GE Gastroenterologists; GERD Gastroesophageal reflux disease; HI Hospital internists; PCP Primary care physicians; PPI Proton pump inhibitor. From reference 5 with permission

practice differ widely in this indication. It is striking that the majority of primary care physicians and gastroenterologists in the surveys reviewed by O'Connor (5) did not believe that $H$ pylori infection caused NUD, but unexpectedly $41 \%$ to $66 \%$ of primary care physicians and $27 \%$ to $43 \%$ of gastroenterologists prescribed $\mathrm{H}$ pylori eradication treatment. This is a striking example of the disconnect between belief and practice, and it probably reflects the frustration that clinicians experience in treating NUD with other therapies such as acid suppression $(28,29)$.

Even more controversial is the association of $\mathrm{H}$ pylori infection and gastroesophageal reflux disease (GERD) $(5,30)$. Therefore, it would be expected that clinicians would be perplexed here, and indeed gastroenterologists have reported widely differing views (Table 1). There is an ongoing debate in the literature about whether to offer eradication treatment in the setting of GERD symptoms, and also whether to eradicate infection before prescribing proton pump inhibitors long term to prevent progression of atrophic gastritis $(4,30)$. There remain concerns that $H$ pylori eradication may be associated with an increased risk of esophagitis (30), and indeed in those predisposed to GERD with more severe fundic inflammation causing acid suppression, it seems likely that these concerns are justified (31). On the other hand, eradication of $H$ pylori infection, even in this setting, appears not to lead to severe esophagitis, and eradication therapy does not significantly increase reflux symptoms $(32,33)$. O'Conner (5) noted that there were widespread country-specific differences in attitudes here (Table 1), but clinician beliefs and practice in terms of this indication have been understudied.

In contrast to NUD and GERD, it might be expected that treatment of $\mathrm{H}$ pylori-positive peptic ulcer disease, for which the evidence is unassailable and has been widely disseminated for over a decade (3), would be a different proposition in terms of a uniform treatment approach. Indeed, based on the surveys reviewed by O'Connor (5), most clinicians state that they would offer therapy to a patient with duodenal ulcer. However, surprisingly, a sizable minority of gastroenterologists and primary care physicians appeared not to believe that $\mathrm{H}$ pylori infection is a cause of gastric ulcer, although most reported that they would offer eradication therapy anyway; this may reflect the controversy over the interaction of $H$ pylori and nonsteroidal anti-inflammatory drugs in gastric ulcer $(34,35)$. Notably, it has taken over 10 years for clinicians to accept the proposition that $H$ pylori treatment is indicated in ulcer disease, reflecting a relatively slow diffusion of the evidence base to the bedside.

Other evidence suggests that despite the survey responses, there is a disconnect between what happens in practice and what clinicians say they do. In ulcer bleeding, where testing and treating $H$ pylori infection is universally considered mandatory $(3,4)$, Tytgat (36) reported that $H$ pylori was only tested for in one-third of patients, and of those testing positive, only one-third were successfully treated. Arguably, this reflects a breakdown in the follow-up of bleeders post hospital discharge because control of bleeding rather than diagnosis of $H$ pylori infection has traditionally been the focus of emergency care. However, the findings remain disturbing because others have observed similar dismal results, although admittedly the surveys all originated in the early 1990s and might not reflect current practice $(37,38)$. A study from Leeds documented that only $30 \%$ of patients with dyspepsia and a proven history of peptic ulcer disease received $\mathrm{H}$ pylori eradication therapy in primary care (39). Other data support the underprescribing of eradication therapy for ulcer disease in primary and secondary care, and they have led to the concept of search and treat in clinical practice (40).

\section{EVIDENCE FOR THERAPEUTIC CONFUSION IN TREATMENT REGIMENS}

Another area of potential confusion relates to what should be optimally prescribed as first-line eradication therapy. The guidelines here have been consistent. For example, the Maastricht 2-2000 Consensus Report (4) recommends a proton pump inhibitor or ranitidine bismuth citrate combined with clarithromycin and amoxicillin as first-line primary care treatment; it is further recommended that patients for whom this treatment fails receive bismuth, metronidazole, tetracycline, and a proton pump inhibitor. Studies from the United States indicate that by the late 1990s, proton pump inhibitor combinations were most often prescribed by gastroenterologists but not primary care physicians, in contrast to Europe where both gastroenterologists and primary care physicians used proton pump inhibitors often (18-20). On the basis of a survey of pharmacies, Lee et al (6) reported that eradication regimens in Ireland varied markedly in terms of the acid suppression agent used; one in five patients was prescribed a different regimen. Other serious anomalies remain; for example, the elderly are less likely to receive eradication 
therapy, although ulcer complications in this age group are often devastating $(41,42)$.

Notably, after eradication therapy, many patients continue to be prescribed acid suppression agents. Data suggest that approximately 50\% will receive antisecretory therapy after eradication $(43-45)$. What is less clear is why. Failure to successfully eradicate is one possibility. How often clinicians routinely confirm that $\mathrm{H}$ pylori infection has been cured is poorly documented and the guideline recommendations vary (2-4). In primary care, follow-up of ulcer disease to ensure cure is likely to be low. Less well recognized in practice is that a sizable proportion of patients with ulcers, despite cure of the infection, remain symptomatic (presumably due to NUD) (46). In NUD, it is expected that the majority of patients will fail to obtain long term relief after successful eradication, although this, too, may often be underappreciated (47).

The success rates of even optimal therapeutic regimens in practice is less than ideal. In trials, it has been accepted that less than an $80 \%$ eradication rate is unacceptable based on an intention-to-treat analysis (4). Unfortunately, even optimal therapy prescribed in practice provides less success than is seen in clinical trials. For example, Moayyedi et al (48) in the Leeds Help study randomized 1161 community subjects to triple therapy and 1163 subjects to placebo; the intent-to-treat eradication rate was only $61 \%$, although this rose to $84 \%$ in a subanalysis of those who took all the medication.

\section{REASONS STANDARD THERAPY MAY FAIL IN PRACTICE}

There are many potential explanations for disappointing results in terms of $\mathrm{H}$ pylori eradication in practice. Inaccurate diagnosis should not be an issue if undertaken, unless testing is done only applying inadequate serology assays or the background prevalence of $H$ pylori infection is very low, leading to more false positives even with the best tests (4). Despite the availability of accurate noninvasive tests, in primary care, empiric treatment of $\mathrm{H}$ pylori infection without testing in dyspepsia remains a widespread practice (44). This is likely to lead to unsatisfactory outcomes that may bias the clinician against future prescription of $\mathrm{H}$ pylori therapy and to overtreatment of true noninfected individuals.

Inappropriate choice of therapy does appear to be a barrier, reflecting clinician confusion (6). There may be country-specific issues that contribute to the confusion. For example, in the United States, each drug has to be written separately on a prescription multiplying the chance for error and requiring clinicians to remember the optimal choice and dose. On the other hand, in many countries, $H$ pylori infection packs are available that enable the clinician simply to remember a brand name, which is presumably easier for the prescriber and reduces dosing errors. To complicate matters, some key drugs are unavailable in certain countries; for example, bismuth is no longer available in Australia because of market forces.

Side effects limit compliance in practice, and the incidence of side effects is probably underestimated if only controlled trial data are considered. In the Leeds Help study (48), 45\% of patients had adverse events in the triple therapy group, and this was much higher than was observed in the placebo group.

Bacterial resistance is an issue that can lead to failure. Metronidazole resistance is a major problem ranging from $20 \%$ to $70 \%$ across the world, while clarithromycin resistance is increasing and ranges from $1 \%$ to $13 \%$; amoxicillin resistance remains rare $(49,50)$. However, the exact role of resistance in treatment failure may be more complex than has initially been appreciated because it is now recognized that there can be multiple bacterial strains in the stomach comprising resistant and sensitive bacteria (51).

Low socioeconomic status may drive poorer results in practice. Lane et al (52) in Bristol found that rates of participation in an adult population being offered $H$ pylori therapy as part of a community randomized-controlled trial were significantly lower in those from lower socioeconomic strata.

\section{VALUE OF GUIDELINES AND STRATEGIES TO IMPROVE THEIR IMPACT}

Much effort has been expended in creating national and international guidelines for dyspepsia and $\mathrm{H}$ pylori infection management, but the impact has been far less than was hoped. Guidelines need to be simple and firmly evidence based. Arguably, opinion at times has swayed the consensus groups as experts grapple with incomplete and flawed data. The guidelines themselves often disagree on specific issues, generating more confusion and mistrust (2-4). Many factors may influence the uptake of guidelines in various ways, including fear of litigation (that may promote use) versus financial incentives, colleagues' recommendations, and personal experience (that may hinder use) (53). It would be interesting to know if gastroenterologists suffering with dyspepsia follow their specialist societies' guidelines on management.

Publication in a journal or simply mailing guidelines to primary care doctors is highly unlikely to significantly alter practice (54). Grol et al (55) evaluated the attributes of clinical guidelines that influenced their use in general practice; this was based on an observational study of the use of 47 different recommendations from 10 national clinical guidelines. It was found that compliance was significantly impaired when the recommendations were controversial and not compatible with current values, were vague and not precisely defined, and demanded changes to fixed routines (55). Hence, guidelines need to specifically ensure that they include an explicit description of the scientific evidence in support, address how to manage negative reactions in patients (such as may occur with side effects of $H$ pylori eradication treatment), and emphasize why the management recommendations are important both for doctors and for patients.

Often, guidelines do not alter practice (56). Grimshaw and Russell $(57,58)$ performed a systematic review of 91 studies. They noted that the best chance of altering clinical behaviour would occur when the guidelines were developed by clinicians for whom they were intended (eg, by primary care doctors for primary care doctors), were disseminated using a specific educational program approach and employed patient-specific reminders during consultations. It was suggested by Meineche-Schmidt et al (59) that algorithms applying a reductionist approach often lose relevance in primary care. Indeed, the diffusion of guidelines developed by specialist societies to primary care often seem to be overlooked or even viewed with suspicion. The development of guidelines by primary care groups and the facilitation of local guideline development must be a priority. If guidelines can be effectively brought to the attention of the doctor during a consultation or are part of the order process, adoption appears to be increased (60). O'Connor (5) suggested that face-to-face education of the physician should be encouraged and described a method of academically based detailing that might be useful. However, such an approach is not likely to be possible because of cost constraints.

\section{THE FUTURE}

Despite the best evidence, ulcer disease currently remains underrecognized and undertreated in many parts of the world, while NUD, a more controversial indication, is frequently a target of $H$ pylori infection therapy. Who to treat and what to treat with continues to confuse too many clinicians at the coal face. Strategies that may improve intervention for $\mathrm{H}$ pylori infection outcomes in primary and secondary care include ensuring that $H$ pylori management guidelines are clear, succinct, authoritative 
and avoid very controversial recommendations; promoting the local development of guidelines; and involving patients directly in the implementation of them.

\section{REFERENCES}

1. Talley NJ. Dyspepsia management in the millennium: The death of test and treat? Gastroenterology 2002;122:1521-5.

2. McNamara D, O'Morain C. Consensus guidelines: Agreement and debate surrounding the optimal management of Helicobacter pylori infection. Can J Gastroenterol 2000;14:511-7.

3. NIH Consensus Conference. Helicobacter pylori in peptic ulcer disease. NIH Consensus Development Panel on Helicobacter pylori in peptic ulcer disease. JAMA 1994;272:65-9.

4. Malfertheiner P, Megraud F, O'Morain C, et al. Current concepts in the management of Helicobacter pylori infection - the Maastricht Consensus Report 2-2000. Aliment Pharmacol Ther 2002;16:167-80.

5. O'Connor HJ. Helicobacter pylori and dyspepsia: Physician's attitudes, clinical practice and prescribing patterns. Aliment Pharmacol Ther 2002;16:487-96.

6. Lee JM, Deasy E, O'Morain CA. Helicobacter pylori eradication therapy: A discrepancy between current guidelines and clinical practice. Eur J Gastroenterol Hepatol 2000;12:433-7.

7. Christensen AH, Logan RPH, Noach LA, Gjorup T. Do clinicians accept the role of Helicobacter pylori in duodenal ulcer disease: A survey of European gastroenterologists and general practitioners. J Intern Med 1994;236:501-5.

8. Milne R, Logan RPH, Harwood D, Misiewicz JJ, Forman D. Helicobacter pylori and upper gastrointestinal disease: A survey of gastroenterologists in the United Kingdom. Gut 1995;37:314-8.

9. Hirth RA, Fendrick AM, Chernew ME. Specialist and generalist physicians' adoption of antibiotic therapy to eradicate Helicobacter pylori infection. Med Care 1996;34:1199-204.

10. Fendrick AM, Hirth RA, Chernew ME. Differences between generalist and specialist physicians regarding Helicobacter pylori and peptic ulcer disease. Am J Gastroenterol 1996;91:1544-8

11. Boekema PH, Veenendaal RA, van Berge-Henegouwen GP. After a decade of Helicobacter pylori in the Netherlands. A survey of the practice of the members of the Dutch Society of Gastroenterology. Neth J Med 1997;51:129-33.

12. Breuer T, Sudhop T, Goodman KJ, Graham DY, Malfertheiner P. How do practicing clinicians manage Helicobacter pylori-related gastrointestinal diseases in Germany? A survey of gastroenterologists and family practitioners. Helicobacter 1998;3:1-8.

13. Breuer T, Goodman KJ, Malaty HM, Sudhop T, Graham DY. How do clinicians practicing in the U.S. manage Helicobacter pylori-related gastrointestinal diseases? A comparison of primary care and specialist physicians. Am J Gastroenterol 1998;93:553-61

14. Martinez-Sanchez G, Saperas E, Benavent J, et al. The attitude of primary health care physicians in the Metropolitan area of Barcelona (Spain) about the diagnosis and treatment of infection by Helicobacter pylori in gastroduodenal diseases. Gastroenterol Hepatol 1998;21:473-8.

15. Binek J, Fantin AC, Meyenberger C. Attitude to Helicobacter pylori infection among Swiss gastroenterologists. Schweiz Me Wochenschr 1999;129:441-5.

16. Martin P, Scheel Thomsen A, Rautanen K, Hjalt C-A, Jonsson A, Lofroth G Diffusion of knowledge of Helicobacter pylori and its practical application by Nordic clinicians. Scand J Gastroenterol 1999;34:974-80.

17. Sharma VK, Vasudeva R, Howden CW. A survey of gastroenterologists' perceptions and practices related to Helicobacter pylori infection. Am J Gastroenterol 1999;94:3170-4

18. Olafsson S, Berstad A. Therapy and diagnostic tests used for Helicobacter pylori infection in the Scandinavian countries in 1998. Scand J Gastroenterol 1999;34:849-55.

19. Zoorob RJ, Jones GN, Mainous AG, Hagen MD. Practice patterns for peptic ulcer disease: Are family physicians testing for $\mathrm{H}$ pylori? Helicobacter $1999 ; 4: 243-8$.

20. Maconi G, Tosetti C, Miroglio G, et al. Management of Helicobacter pylorirelated gastrointestinal diseases by general practitioners in Italy. Aliment Pharmacol Ther 1999;13:1499-504.

21. Moayyedi P, Soo S, Deeks J, et al. Systematic review and economic evaluation of Helicobacter pylori eradication treatment for non-ulcer dyspepsia. BMJ 2000;321:659-64.

22. Moayyedi P, Feltbower R, Brown J, et al. Effect of population screening and treatment for Helicobacter pylori on dyspepsia and quality of life in the community: A randomized controlled trial. Lancet 2000;355:1665-9.

23. Danesh J, Lawrence M, Murphy M, Roberts S, Collins R. Systematic review of the epidemiological evidence on Helicobacter pylori infection and nonulcer or uninvestigated dyspepsia. Arch Intern Med 2000;160:1192-8.

24. Laine L, Schoenfeld P, Fennert MB. Therapy for Helicobacter pylori in patients with nonulcer dyspepsia: A meta-analysis of randomized, controlled trials. Ann Intern Med 2001;134:361-9.

25. Pantoflikova D, Blum AL. Antagonist: Should we eradicate Helicobacter pylori in non-ulcer dyspepsia? Gut 2001;48:758-9.

26. McColl KEL. Protagonist: Should we eradicate Helicobacter pylori in non-ulcer dyspepsia? Gut 2001;48:759-61.

27. Talley NJ, Hunt RH. What role does Helicobacter pylori play in dyspepsia and nonulcer dyspepsia? Arguments for and against $\mathrm{H}$ pylori being associated with dyspeptic symptoms. Gastroenterology 1997;113:S67-77.

28. Talley NJ, Silverstein M, Agreus L, et al. AGA technical review: Evaluation of dyspepsia. Gastroenterology 1998;114:582-95.
29. Talley NJ, Axon A, Bytzer P, et al. Management of uninvestigated and functional dyspepsia: A working party report for the World Congress of Gastroenterology 1998. Aliment Pharmacol Ther 1999;13:1132-48.

30. Labenz J, Malfertheiner P. Helicobacter pylori in gastro-esophageal reflux disease: Causal agent, independent or protective factor? Gut 1997:41:277-80,

31. Hamada H, Haruma K, Mihara M, et al. High incidence of reflux esophagitis after eradication therapy for Helicobacter pylori: Impacts of hiatal hernia and corpus gastritis. Aliment Pharmacol Ther 2000;14:729-35.

32. Moayyedi P, Bardhan C, Young L, et al. Helicobacter pylori eradication does not exacerbate reflux symptoms in gastroesophageal reflux disease. Gastroenterology 2001;121:1120-6.

33. Talley NJ, Janssens J, Lauritsen K, et al. No increase of reflux symptoms or esophagitis in patients with non-ulcer dyspepsia 12 months after Helicobacter pylori eradication: A randomized double-blind placebo-controlled trial. Gastroenterology 1998;114:A306.

34. Hawkey CJ, Tulassay Z, Szczepanski L, et al. Randomized controlled trial of Helicobacter pylori eradication in patients on non-steroidal anti-inflammatory drugs: HELP NSAIDs study. Lancet 1998;352:1016-21.

35. Chan FK, Chung SC, Suen BY, et al. Preventing recurrent upper gastrointestinal bleeding in patients with Helicobacter pylori infection who are taking low-dose aspirin or naproxen. N Engl J Med 2001;344:967-73.

36. Tytgat GNJ. Treatment of Helicobacter pylori infection: Management of patients with ulcer disease by general practitioners and gastroenterologists. Gut 1998:43:S24-6

37. Roll J, Weng A, Newman J. Diagnosis and treatment of Helicobacter pylori infection among California Medicare patients. Arch Intern Med 1997;157:994-8.

38. Ofman JJ, Etchason J, Alexander W, et al. The quality of care for Medicare patients with peptic ulcer disease. Am J Gastroenterol 2000;95:106-13.

39. Bodger K, Daley MJ, Heatley RV. Prescribing patterns for dyspepsia in primary care: A prospective study of selected general practitioners. Aliment Pharmacol Ther 1996;10:889-95.

40. de Boer WA. Topics in Helicobacter pylori infection: Focus on a 'search and treat' strategy for ulcer disease. Scand J Gastroenterol 2000;232(Suppl):4-9.

41. Pilotto A, Malfertheiner P. An approach to Helicobacter pylori infection in the elderly. Aliment Pharmacol Ther 2002;16:683-91.

42. Pilotto A, Franceschi M, DiMario F. Helicobacter pylori-associated peptic ulcer disease in elderly patients. Clin Geriatrics 2000;8:49-58.

43. Juul KV, Ostergaard Thomsen O, Nissen A, et al. National surveillance of Helicobacter pylori eradication therapy in Denmark. Results from registration of 34,582 prescriptions. Scand J Gastroenterol 1998;33:928-32.

44. Heaney A, Collins JSA, Watson RGP, Kalin RM. General practitioners' habits and knowledge in relation to the management of $\mathrm{H}$ pylori-associated dyspepsia and their views about locally available 13-carbon urea breath test. Br J General Pract 2000;50:221-2.

45. Munnangi S, Sonnenberg A. Time trends of physician visits and treatment patterns of peptic ulcer disease in the United States. Arch Intern Med 1997;157:1489-94.

46. Quan C, Talley NJ. Management of peptic ulcer disease not related to Helicobacter pylori or NSAIDs. Am J Gastroenterol 2002;97:2950-61.

47. Talley NJ, Quan C. Helicobacter pylori and non-ulcer dyspepsia. Aliment Pharmacol Ther 2002;16(Suppl 1):58-65.

48. Moayyedi P, Feltbower R, Crocombe W, et al. The effectiveness of omeprazole, clarithromycin and tinidazole in eradication Helicobacter pylori in a community screen and treat programme. Leeds Help Study Group. Aliment Pharmacol Ther 2000;14:719-28.

49. Quasim A, O'Morain CA. Treatment of Helicobacter pylori infection and factors influencing eradication. Aliment Pharmacol Ther 2002;16(Suppl 1):24-30.

50. Xia HX, Kalantar SJ, Talley NJ. Metronidazole- and clarithromycin-resistant Helicobacter pylori in dyspeptic patients in Western Sydney as determined by testing multiple isolates from different gastric sites. J Gastroenterol Hepatol 1998;13:1044-9.

51. Wong BC, Wang WH, Berg DE, et al. High prevalence of mixed infections by Helicobacter pylori in Hong Kong: Metronidazole sensitivity and overall genotype. Aliment Pharmacol Ther 2001;15:493-503.

52. Lane JA, Harvey RF, Murray LJ, et al. A placebo-controlled randomized trial of eradication of Helicobacter pylori in the general population: Study design and response rates of the Bristol Helicobacter Project. Control Clin Trials 2002;23:321-32.

53. Greer AL. The state of art versus the state of science: The diffusion of new medical technologies into practice. Int J Technol Health Care 1988;4:5-26.

54. Grimshaw JM, Russell IT. Achieving health gains through clinical guidelines II. Ensuring that guidelines change medical practice. Qual Health Care 1994;3:45-52.

55. Grol R, Dalhuijsen J, Thomas S, Veld C, Rutten G, Mokkink H. Attributes of clinical guidelines that influence use of guidelines in general practice: Observational study. BMJ 1998;317:858-61.

56. Lomas J, Anderson GM, Domnick-Pierre K, Vayda E, Enkin MW, Hannah WJ. Do practice guidelines guide practice? The effect of a consensus statement on the practice of physicians. N Engl J Med 1989;321:1306-11.

57. Grimshaw JM, Russell IT. Effect of clinical guidelines on medical practice: A systematic review of rigorous evaluations. Lancet 1993;342:1317-22.

58. Grimshaw JM, Russell IT. Implenting clinical practice guidelines: Can guidelines be used to improve clinical practice? Effective Health Care 1994:8:1-12

59. Meineche-Schmidt V, Rubin G, de Wit NJ. Helicobacter pylori infection: A comparative review of existing management guidelines. Fam Pract 2000;17:S2-5.

60. Thomson R, Lavender M, Madhok R. How to ensure that guidelines are effective. BMJ 1995;311:237-42. 


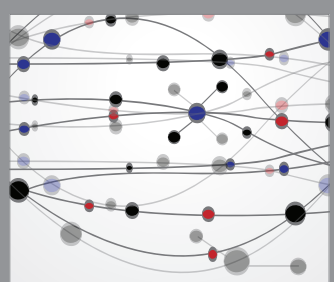

The Scientific World Journal
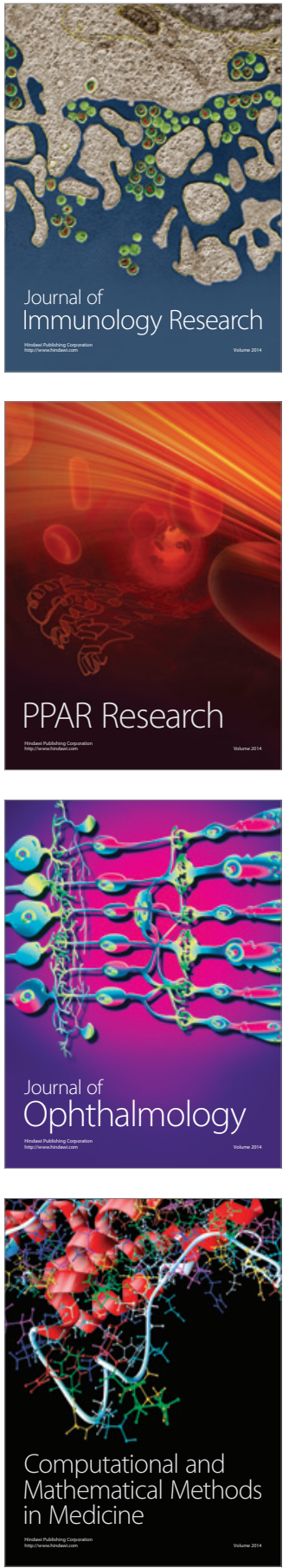

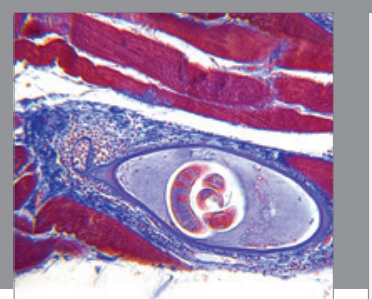

Gastroenterology Research and Practice

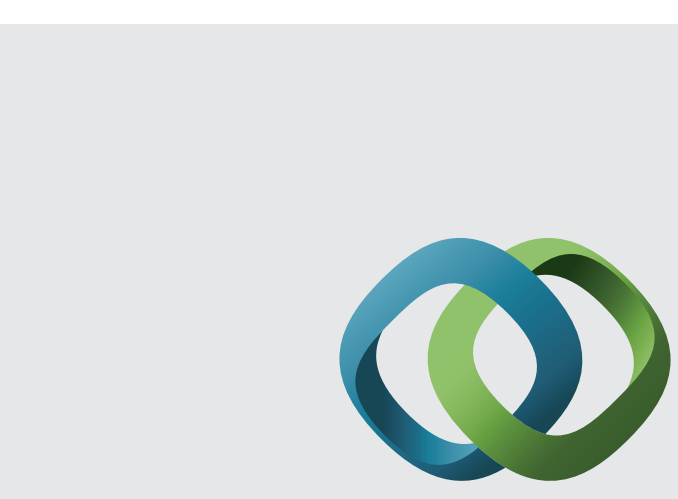

\section{Hindawi}

Submit your manuscripts at

http://www.hindawi.com
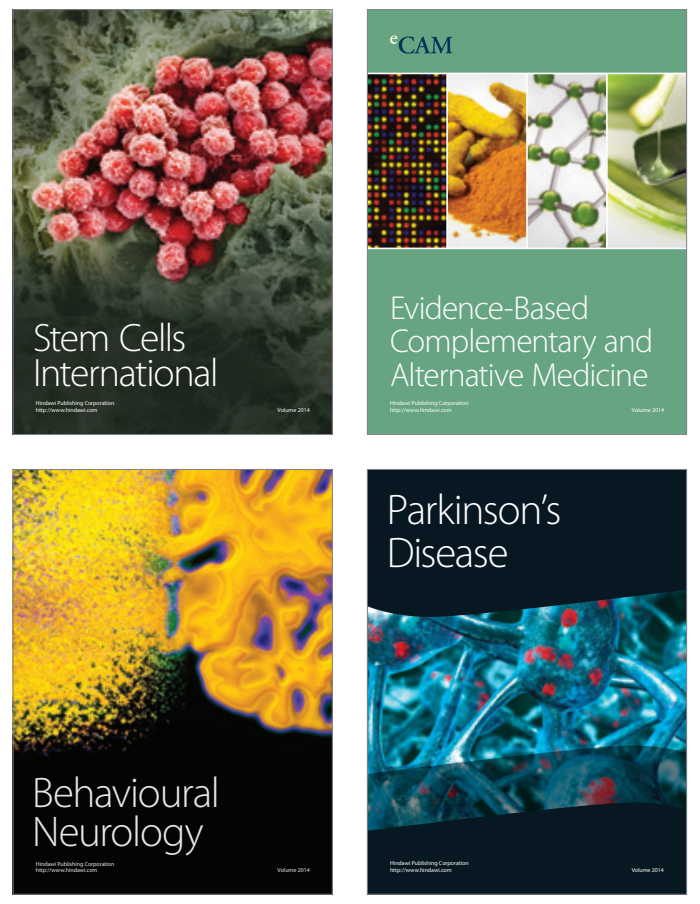
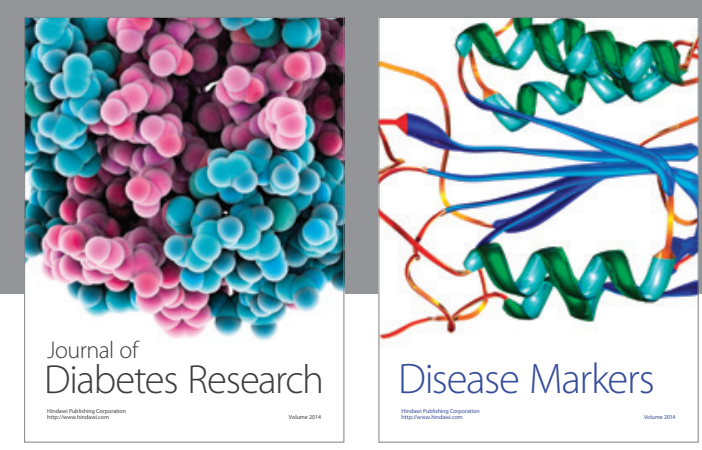

Disease Markers
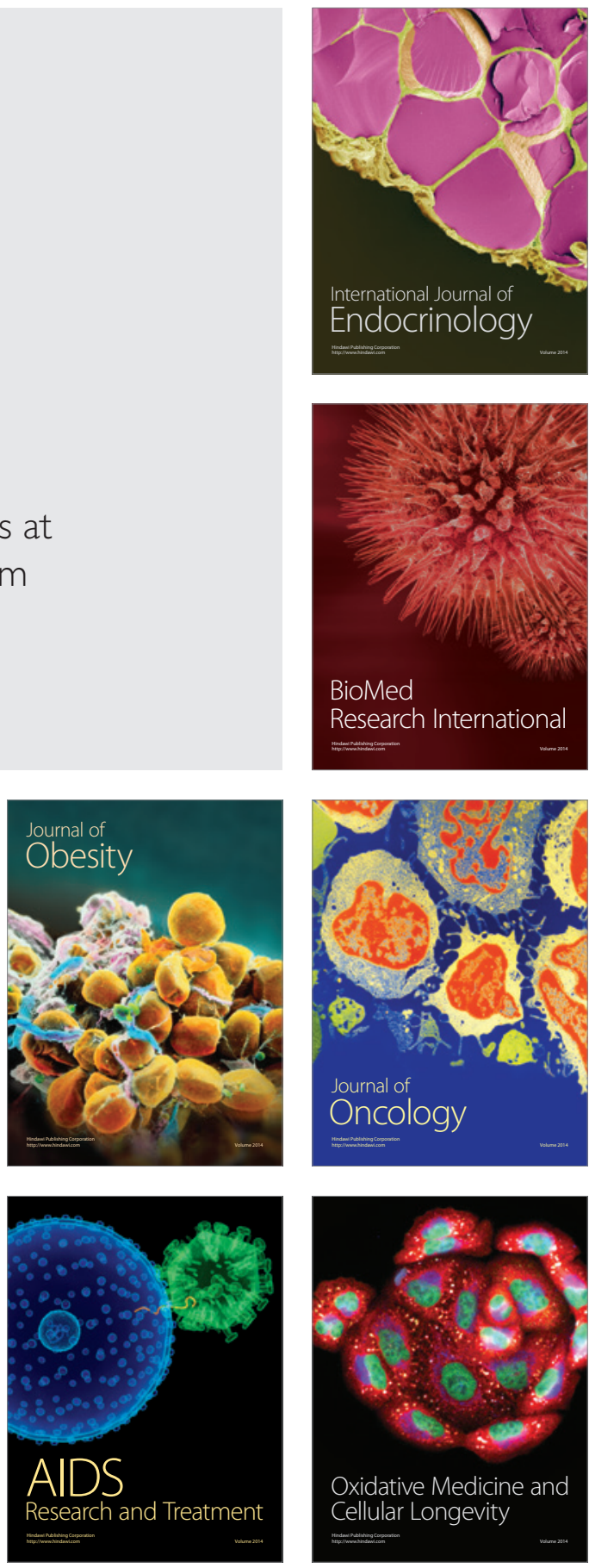